\title{
Assessment and conservation status of an endemic bee in a diversity hotspot (Hymenoptera, Melittidae, Dasypoda)
}

\author{
Guillaume Ghisbain', Vladimir G. Radchenko², Diego Cejas', \\ Francisco P. Molina ${ }^{3}$, Denis Michez'
}

I Laboratory of Zoology, Research Institute for Biosciences, University of Mons, Place du parc 20, 7000, Mons, Belgium 2 Institute for Evolutionary Ecology of the National Academy of Sciences of Ukraine, acad. Lebedev, 37, Kiev 03143, Ukraine 3 Departamento de Ecología Integrativa, Estación Biológica de Doñana (EBDCSIC), Avda. Américo Vespucio S/N Isla de la Cartuja, 41092, Sevilla, Spain

Corresponding author: Guillaume Ghisbain (guillaume.ghisbain@umons.ac.be)

Academic editor: J. Neff | Received 16 November 2020 | Accepted 17 December 2020 | Published 25 February 2021

http://zoobank.org/666A641C-7B44-4314-8798-7212285B8E8A

Citation: Ghisbain G, Radchenko VG, Cejas D, Molina FP, Michez D (2021) Assessment and conservation status of an endemic bee in a diversity hotspot (Hymenoptera, Melittidae, Dasypoda). Journal of Hymenoptera Research 81: 127-142. https://doi.org/10.3897/jhr.81.60811

\begin{abstract}
Wild bees represent a global group of highly diversified insect pollinators, nowadays concerningly well known for their widespread observed patterns of decline. Amongst them is the genus Dasypoda, a widespread Palearctic clade of solitary bees generally poorly represented in entomological collections. Among the 39 accepted species of the genus, 35 are known by both sexes, and a large number of taxa are still known by a low number of specimens. The recently described taxon Dasypoda (Heterodasypoda) michezi Radchenko, 2017 endemic to southern Portugal is just such a case. The species was described from two male specimens, but no female material has been known to date. Here, we provide the first description of the female of $D$. michezi, collected close to the locus typicus in southern Portugal along with a series of conspecific males. Sex pairing is proposed based on the sympatry of the male and female specimens and on the similar morphology of non-sexual dimorphic traits and on the barcode of a fragment of Cytochrome Oxidase I. We provide high quality imaging of both sexes of $D$. michezi to help future identification of the species and present a key for all known species of the subgenus Heterodasypoda. We finally propose an IUCN status for D. michezi and discuss the conservation of such geographically restricted species in the current context of global change.
\end{abstract}

\section{Keywords}

Conservation, Dasypoda michezi, endemism, Heterodasypoda, Iberia, IUCN, Portugal, taxonomy

Copyright Guillaume Ghisbain et al. This is an open access article distributed under the terms of the Creative Commons Attribution License (CC BY 4.0), which permits unrestricted use, distribution, and reproduction in any medium, provided the original author and source are credited. 


\section{Introduction}

Wild bees constitute a highly diversified group of pollinating insects, comprising more than 20,000 described species globally (Michener 2007). Approximately a tenth of this global diversity can be found in Europe, one of the most studied places for bee diversity, biogeography and life history in the world (Michez et al. 2019). Concerningly, global changes have triggered widespread population declines across several clades of wild bees, making this group of pollinators widely studied for conservation purposes (e.g. Potts et al. 2010; Nieto et al. 2014). As for all other animals, nevertheless, the effective species-level conservation of bees relies on an unambiguous taxonomic delineation and identification. This principle is well exemplified in Red Lists and large-scale biogeographic studies for which species inventories and occurrence records constitute the starting point for geographic projections and assessments (Nieto et al. 2014; Rasmont et al. 2015; Ghisbain et al. 2020b).

Amongst the bee families represented in Europe is the Melittidae, a species-poor bee family globally (Michez et al. 2009). Among melittids, the genus Dasypoda Latreille is remarkable in its unique morphology, specifically by the presence of well-developed pollen-carrying hair structures (scopae) on the tibia and basitarsus of the hind legs of the females (Michener 2007; Michez et al. 2019). The genus is predominantly distributed in the Palearctic region, except for a single sub-Saharan species (Michez and Pauly 2012). To date, 39 valid species are recognized with 35 of them known from both sexes (Radchenko et al. 2019). Four subgenera are currently recognized within Dasypoda, with their centers of diversity found in parts of the Mediterranean region: the Balkans, Morocco and the Iberian Peninsula. Unlike the situation in many groups of wild bees, there continue to be significant additions to the knowledge of the Dasypoda fauna of Europe, with the description of new species (Radchenko 2016, 2017) and new records for many countries (Schmid-Egger and Dubitzky 2017; Ghisbain et al. 2018; Shebl 2018; Radchenko et al. 2019, 2020; Wendzonka et al. 2020).

The most recently described species of the genus, Dasypoda michezi Radchenko, 2017 , is a very localized bee known only from two males collected in two nearby localities in the south-west of Portugal (Radchenko 2017), a biodiversity hotspot for bees (Baldock et al. 2018). The species belongs to the subgenus Heterodasypoda Michez, characterized in males by conspicuous morphological autapomorphies, i.e. sternum 7 comprising two large, membranous lateral structures and the genitalia consisting of three distinct lobes, the inner one with a scaly surface (Michez et al. 2004b). The male of Dasypoda michezi is distinguishable from its congeners by several features including the diagnostic sculpture and shape of the glossa, galea and sterna. To date however, the female of this taxon has not been described (Radchenko 2017).

In this paper, we combine the use of molecular barcoding and the study of morphological traits to provide the first description of the female of Dasypoda michezi. The description is based on two individuals collected along with a longer set of males in the south of Portugal, close to the locus typicus of the species. We then assess the conservation status of this overlooked bee species and discuss its conservation as an endemic bee in a diversity hotspot. 


\section{Material and methods}

\section{Sampling}

We examined a series of Dasypoda (Heterodasypoda) specimens collected in southern Portugal in the years 2005-2006 by M. and E. Howe, following the taxonomic key from Michez et al. (2004a). The morphological characteristics of two females could be identified as those of Heterodasypoda but did not correspond to any previously known Dasypoda species (following Michez et al. 2004a), while the males could be determined as Dasypoda michezi Radchenko following the detailed description provided by Radchenko (2017).

\section{Genetic analyses}

We sequenced a fragment of the cytochrome oxidase I (COI) gene from these two female specimens and from sympatric males of Dasypoda michezi. DNA was extracted from a middle leg of every individual using the Nucleo spin Tissue kit (MachereyNagel, Germany) following manufacturer instructions with a lower volume of elution buffer and expanded final incubation times to improve DNA yield. As pinned specimens from old collections ( $>10$ years) can be difficult to sequence (i.e. their DNA has degraded over time and moreover is affected by the different processes of preservation of the collections), it is advisable to amplify small amplicons ( $<200 \mathrm{bp}$ ) (Wandeler et al. 2007). Therefore, modified LEP primers for older samples (LEP-F1/LEP-R2, Hebert et al. 2004) were selected to amplify a fragment of the cytochrome oxidase subunit 1 (COI) gene, a region commonly used to study the taxonomic status of animals, and frequently used in bee taxonomy (e.g. Orr et al. 2018; Weissmann et al. 2018; Ghisbain et al. 2020a). After Sanger sequencing (Eurofins Genomics, Spain) and alignment of the cleaned sequences, we ran a neighbor-joining phylogeny with 10,000 bootstraps including D. michezi ( $\mathrm{n}=7$, including the two female specimens) along with representatives of each species of Heterodasypoda: D. morotei Quilis, $1928(\mathrm{n}=2)$, D. pyrotrichia Förster, $1855(\mathrm{n}=1), D$. albimana Pérez, $1905(\mathrm{n}=3)$. We chose the slightly more distant Dasypoda (Microdasypoda) crassicornis Friese, 1896 as an outgroup.

\section{Taxonomy}

Based on the results of the genetic barcoding (see below), we further examined the morphology of these females in comparison with that of the males and that of the other species of Heterodasypoda (i.e. Dasypoda albimana, D. morotei and D. pyrotrichia). High-quality pictures of both sexes of $D$. michezi were taken using a Canon EOS 5DS R (Canon Inc., Tokyo, Japan) camera assembled onto a stereomicroscope Leica M205C (Leica Microsystems, Wetzlar, Germany) with Leica LED5000 HDI illuminator under Helicon Remote 3.9.7.w. software. Photographs were then combined into a single image using Helicon Focus 7.5.6 Pro (Helicon Soft Ltd, Kharkiv, Ukraine) automontage software. 
Finally, we established a key to all known species of Heterodasypoda following Michez et al. (2004a, b) and the results of the present study. The following abbreviations, after Michener (2007), are used below: T1, T2 . = first, second, etc. metasomal terga; $\mathrm{S} 1, \mathrm{~S} 2 \ldots$ = first, second, etc. metasomal sterna; $\mathrm{A} 1, \mathrm{~A} 2 \ldots=$ first, second, etc. antennal segments, $\mathrm{pw}=$ puncture width.

\section{Conservation assessment}

We assessed an IUCN status for Dasypoda michezi following the Guidelines for using the IUCN Red List Categories and Criteria V. 14 (https://www.iucnredlist.org/resources/ redlistguidelines) and the protocol of Nieto et al. (2014). To do so, we measured both the area of occupancy (AOO) and extent of occurrence (EOO) of the species. The $\mathrm{AOO}$ is the measure of the area in which a species occurs and corresponds to the sum of the area of grids the species occupies, while the EOO is a measure of the geographic range size of a species and is calculated by drawing a convex hull which is defined as the smallest polygon containing all the sites of occurrence and in which no internal angle exceeds $180^{\circ} \mathrm{C}$.

\section{Results}

\section{Genetic analyses}

The amplified COI fragment of the examined male and female specimens of Heterodasypoda collected in southern Portugal were identical, and distinct from all other species of Heterodasypoda (Fig. 1A). Given that the males morphologically correspond to the original description of Dasypoda (Heterodasypoda) michezi from Radchenko (2017), we can state with confidence that the examined females belong to D. michezi. Updated maps of the Western-Mediterranean distributions of the four known species of Heterodasypoda are given in Figure 1B, C. New sequences are available on Genbank with the accession numbers MW389319-MW389326; MW401790-MW401795.

\section{First description of the females of Dasypoda michezi}

Figures 2-14

Note. We describe for the first time the female of Dasypoda michezi. Specimens examined during the study are deposited in the entomological collection of the Laboratory of Zoology of the University of Mons (Belgium) and in the Institute for Evolutionary Ecology of the National Academy of Sciences of Ukraine.

Material examined. 2 q $ᄋ$, Portugal, Algarve, Sagres Camp/Heath $\left[37.0249^{\circ} \mathrm{N}\right.$, 8.9463 $\left.{ }^{\circ} \mathrm{W}\right], 13 . I V .2006$, leg. M. and E. Howe. 


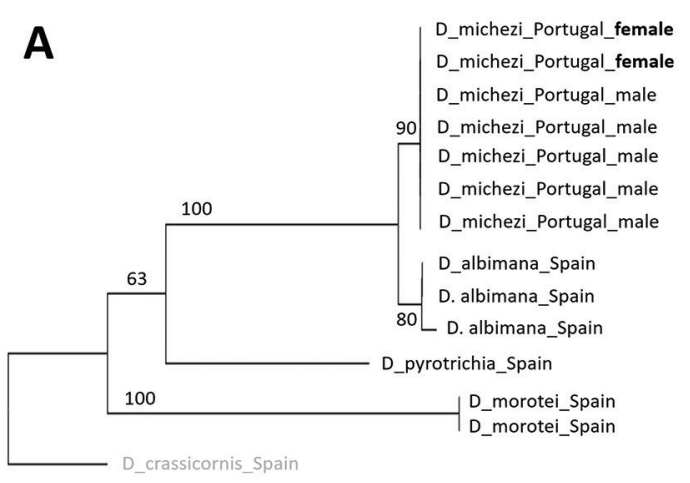

Dasypoda michezi Radchenko, 2017

Dasypoda albimana Pérez, 1905

Dasypoda pyrotrichia Förster, 1855

Dasypoda morotei Quilis, 1928

Dasypoda crassicornis Friese, 1896 [OUTGROUP]
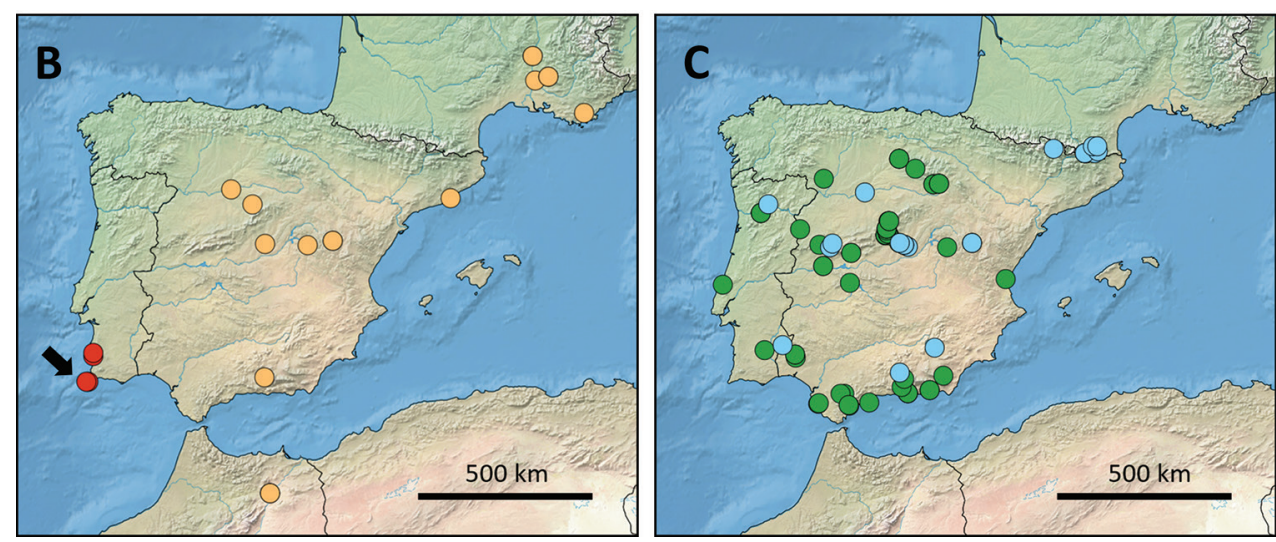

Figure I. A COI phylogeny of the Heterodasypoda, highlighting the association of both female and male specimens of $D$. michezi from southern Portugal, with D. (Microdasypoda) crassicornis as an outgroup B, C West Mediterranean distribution of the four known species of Heterodasypoda: B records of D. albimana (orange) and $D$. michezi (red, new records indicated by the black arrow) $\mathbf{C}$ records of $D$. morotei (green) and D. pyrotrichia (blue). Adapted from Michez et al. (2004) and Radchenko (2017).

\section{Description. Female (Figs 2-15). Body length $=13.5-13.6 \mathrm{~mm}$. Head} (Figs 4-9). W - 3. 55-3.65 mm; H - 3.23-3.25 mm. Face between antennae dull, densely punctured and bearing erect white and dark (brown-black) hairs, proportion of dark hairs greater on lateral parts of face and just below ocellar field. Area in front of ocellae very densely punctured and matt, this puncturing less dense behind ocellar field. Area between lateral ocellae and compound eyes shagreened. Vertex (Fig. 5) with sparse yellow pilosity and dark erect setae. Clypeus densely punctured, punctures less than $1 \mathrm{pw}$ apart, on most of its surface, punctures slightly larger and more separated distally. Medio-distal part of clypeus shiny; distal part with tufts of short white hair mixed with a few darker setae; hairless medially except in some areas with a few white and black setae; basal and lateral parts covered with mixed white and black hairs. Labrum unpunctured and shiny basally; distal part bearing thick orange setae inserted in large punctures. Mandibles black, in some places with 

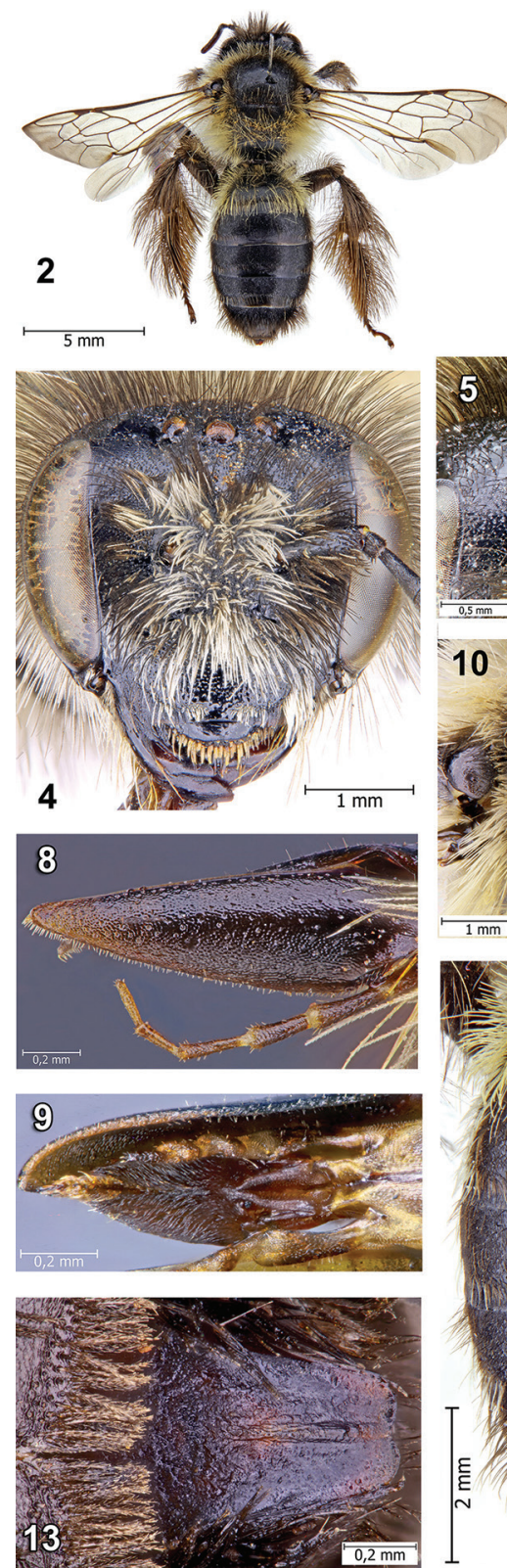
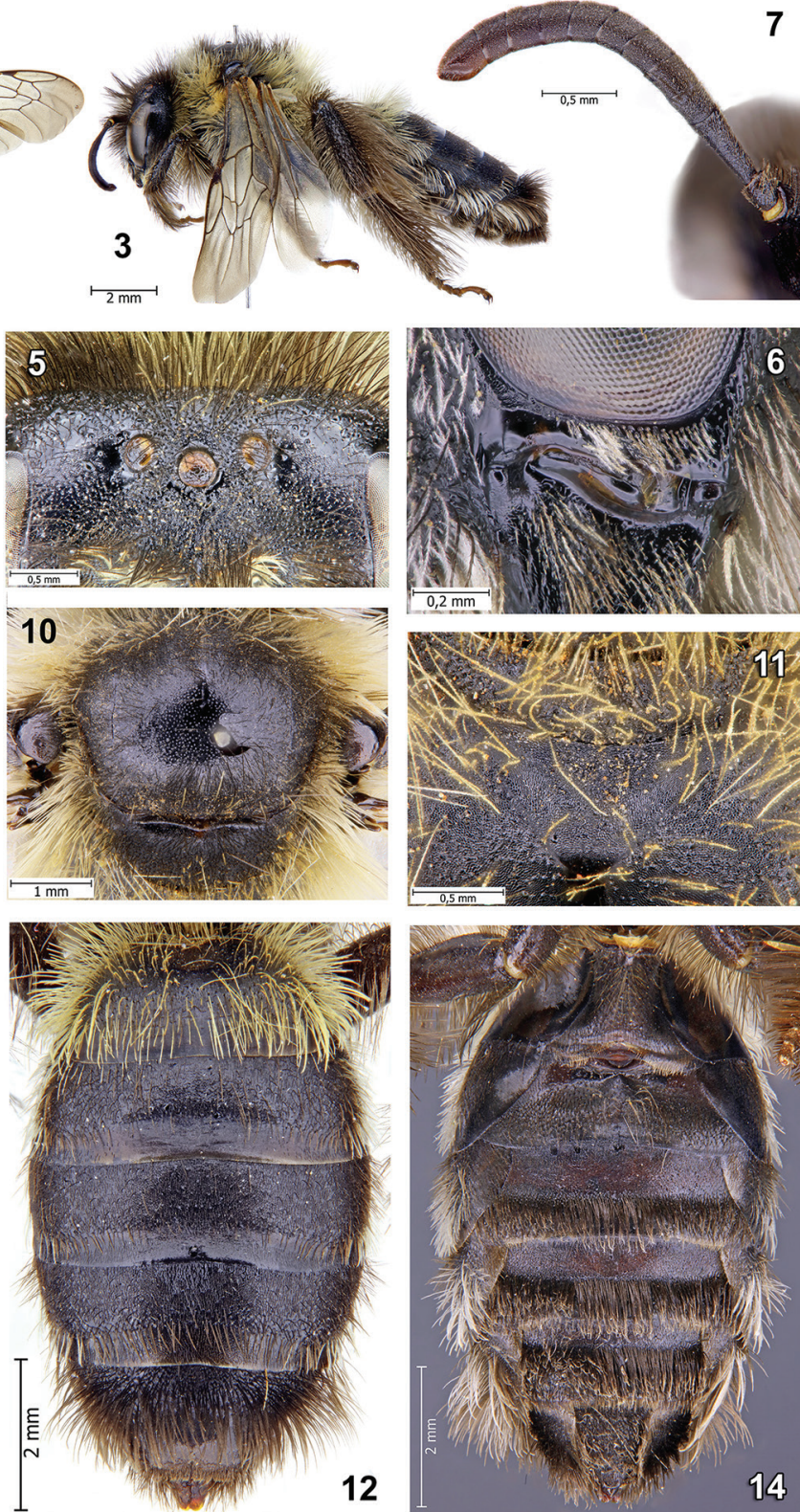

12

Figures 2-14. Female of D. michezi from Algarve, southern Portugal (first description) $\mathbf{2}$ dorsal view $\mathbf{3}$ lateral view $\mathbf{4}$ head (frontal view) $\mathbf{5}$ vertex and ocelli $\mathbf{6}$ malar area $\mathbf{7}$ flagellum and pedicel $\mathbf{8}$ galea and maxillary palpus $\mathbf{9}$ glossa and labial palpus inside the galea (ventral view) $\mathbf{I 0}$ scutum I I metanotum and propodeum $\mathbf{I} \mathbf{2}$ metasoma (dorsal view) $\mathbf{I}$ pygidial plate $\mathbf{1} \mathbf{~ m e t a s o m a ~ ( v e n t r a l ~ v i e w ) . ~}$

dark red shades, bearing long white setae ventrally. Malar space (Fig. 6) shorter than width of mandible at its base, one specimen bearing very short, thick, white, black pilosity. Maxillary palpus and galea subequal. Galea with small tubercles merged 
into sinuous lines on most of its surface; margin of galea with bristles all along its length (Fig. 8). Glossa dark with yellow apical bristles. Maxillary palpi approximately 0.75 times as long as length of glossa (Fig. 9). Scape with sparse dark or white setae; surface shiny, sparsely punctate, punctures large. Last article of antennae truncated at apex (Fig. 7).

Mesosoma (Figs 10, 11). W (between tegulae) - 3.15-3.24 mm. Scutum densely punctured medially (Fig. 10), shagreened between punctures, shiny in center, but matt laterally. Small unpunctured, shiny area in center of scutum with starting point of clearly visible carina extending to the most distal part of scutum. Parapsidal lines very thin and long. Scutum with sparse dark pilosity medially, surrounding parts bearing erect dark and yellowish pilosity, proportion of yellowish hairs greater laterally. Scutellum, metanotum and propodeum (Fig. 11) densely punctured and matt, scutellum bearing a majority of erect dark hairs; metanotum and propodeum mostly with yellowish erect setae. Mesosoma ventrally with dense pure-white pilosity ventrally. Tegulae dark brown, slightly shagreened and shiny. Wings transparent, slightly darkened (Figs 2, 3, 15). Forelegs bearing long brown hairs dorsally, protibia and probasitarsus with short orange pilosity ventrally. Mesotibia with yellowish-whitish pilosity ventrally and brown pilosity dorsally. Mesobasitarsus with orange pilosity ventrally, brown pilosity dorsally and whitish pilosity on its outer face. Metatibia and metabasitarsus with whitish pilosity ventrally and brown pilosity dorsally, metabasitarsus bearing orange pilosity on its posterior surface.

Metasoma (Figs 12-14). L - 7.7-7.8 mm; W (at widest point) - 4-4.5 mm. T1 evenly punctate, surface matt, pilosity as on metanotum and propodeum. T2T4 matt and strongly shagreened, bearing whitish tufts of hair laterally, with very sparse brown pilosity on discs. T5 with denser and longer erect dark pilosity, except lateral part with whitish pilosity as on other terga. Punctures of T5 strong, dense, less than 1 pw apart laterally, but approx. 1 pw medially. Sides of T6 (around pygidial plate) bearing the same dense and long dark pilosity as on T5. Pygidial plate (Fig. 13) hairless, depressed, dark purple, narrowly elongate and bifurcate apically. Sterna thinly shagreened anteriorly with short brown pilosity, strongly punctured posteriorly (Fig. 14).

Additional male material examined. Portugal, Algarve, Sagres Camp/Heath

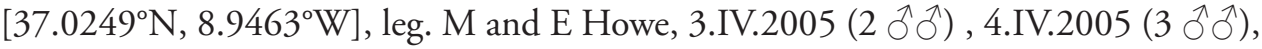

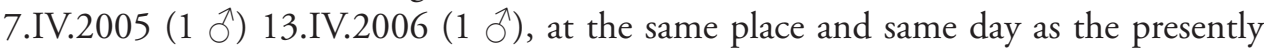
described females); 10 , Portugal, Algarve, Sagres Campsite [same locality, $37.0249^{\circ} \mathrm{N}$, 8.9463 $\left.{ }^{\circ} \mathrm{W}\right], 10 . I V .2006$, leg. $\mathrm{M}$ and E Howe; 1 ते, Portugal, Algarve, Cabo de Sao Vicente $\left[37.0227^{\circ} \mathrm{N}, 8.9964^{\circ} \mathrm{W}\right], 11 . I V .2006$, leg. $\mathrm{M}$ and E Howe. All specimens are deposited in the Laboratory of Zoology (UMons, Belgium).

Phenology and ecology. Flight period. The previous records of $D$. michezi were in late spring $\left(20^{\text {th }}-21^{\text {st }}\right.$ May) (Radchenko 2017). Our new records are from earlier in the season $\left(3^{\text {rd }}-13^{\text {th }}\right.$ April).

Floral choices. Unfortunately, the labels of the newly recorded specimens do not carry floral records. Some labels state "Heath", which may refer to the type of vegetation at the collecting sites and not the visited plant (Erica). 


\section{Key to the species of Heterodasypoda}

\section{Females}

1 Pubescence of mesotibia completely white (ventrally and dorsally)

- Pubescence of mesotibia not entirely white, with at least some yellow or brownish hairs present ............................................................... 2

2 Face with entirely black pilosity. Galea with external surface shiny. Scutum covered with ginger or cream hair. Tegula light orange .......Dasypoda pyrotrichia

- $\quad$ Pilosity of face including at least some lighter hairs. Galea with external surface either matt or shiny. Scutum with dark pilosity in the center, lighter on the sides. Tegula brown ................................................................ 3

3 Mesotibia mostly with plumose white pilosity but including coarse spine-like dark brown hair dorsally (Figs 16-18). Hair band of T4 with sparse, brown pilosity. Ventral part of mesosoma with white pilosity.... Dasypoda michezi

- Mesotibia with plumose white pilosity but including coarse spine-like yellow and light brown hair (Figs 19-21). Hair band of T4 wide and dense, medially white and black on the sides. Ventral part of mesosoma with mixed black and white pilosity

Dasypoda morotei

\section{Males}

Detailed diagnosis of the males of Heterodasypoda is available in Radchenko (2017) and new pictures of are provided in Figures 22-36.

$1 \quad$ Clypeus medially completely punctured..............................................2

- Clypeus medially with an unpunctured longitudinal carina .......................3

$2 \quad$ Galea densely covered with wave-like sculptures (Fig. 28). Glossa six times as long as wide (width taken at its base; Fig. 29) ................ Dasypoda michezi

- Galea with weak inconspicuous sculpting. Glossa three times as long as wide (width taken at its base).....

Dasypoda albimana

3 A3 at most as long as A4. S6 deeply indented at the apical margin. Base of gonostylar internal lobe as wide as external lobe....

Dasypoda morotei

- $\quad$ A3 longer than A4. S6 weakly indented at the apical margin. Base of gonostylar internal lobe wider than the external lobe

Dasypoda pyrotrichia

\section{Conservation status of Dasypoda michezi}

The known EOO of Dasypoda michezi based on all available records encompasses $\sim 199 \mathrm{~km}^{2}$ while its known AOO encompasses $16 \mathrm{~km}^{2}$ (based on $2 \mathrm{~km} \times 2 \mathrm{~km}$ cell width). Both these measures are associated with the category Endangered following the IUCN criteria B1 and B2 and their combination with the condition "a" ([Extent/ Habitat] severely fragmented $O R$ [low] number of locations) since the bee has only been 

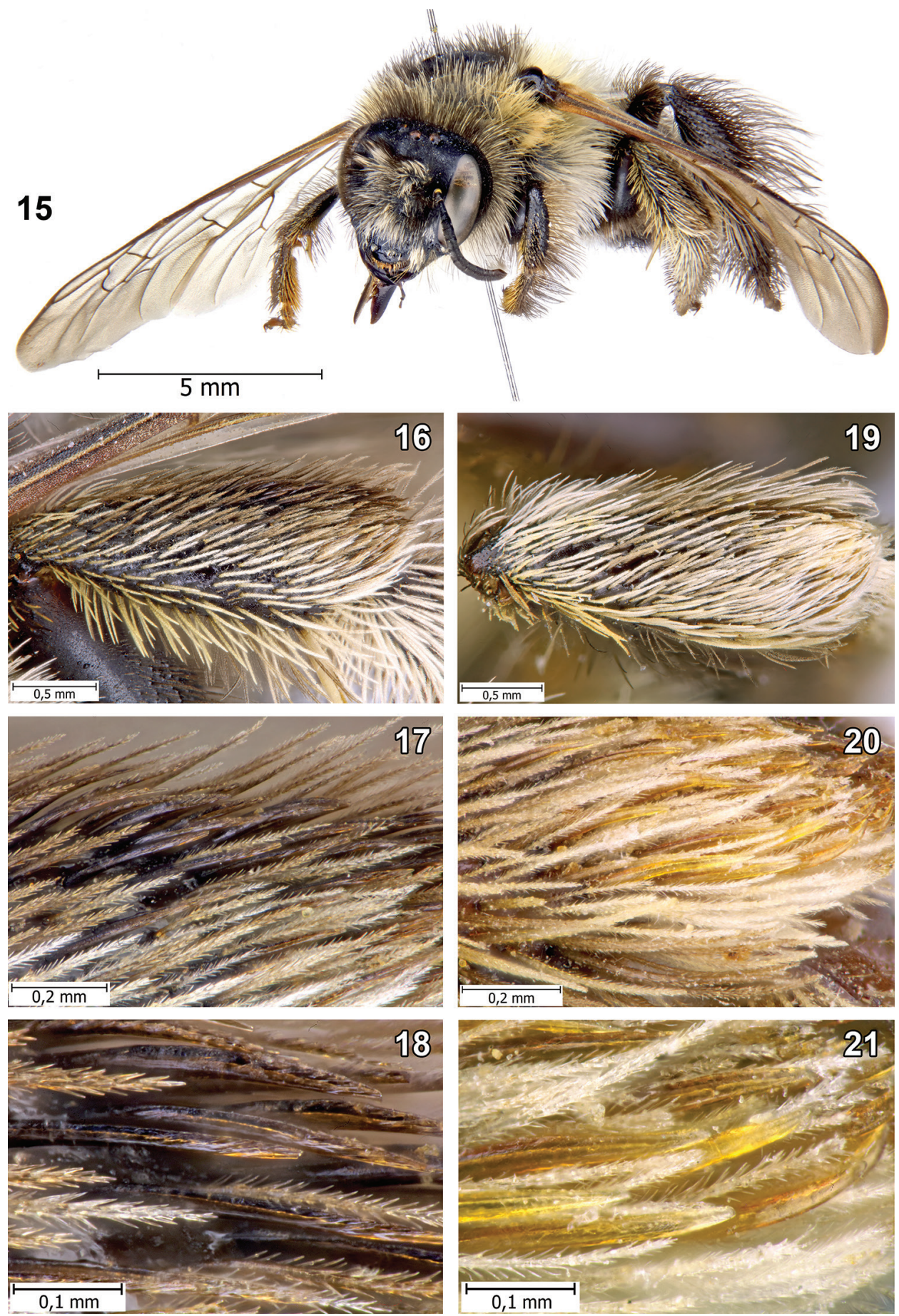

Figures I5-2I. Comparison of the mesotibia pubescence between D. michezi and D. morotei $\mathbf{I 5}$ female of $D$. michezi (fronto-lateral view; the position of the mesotibia is the same as in Fig. 16) 16-18 pubescence of $D$. michezi mesotibia under different magnifications | 9-2I Pubescence of $D$. morotei mesotibia under different magnifications. 


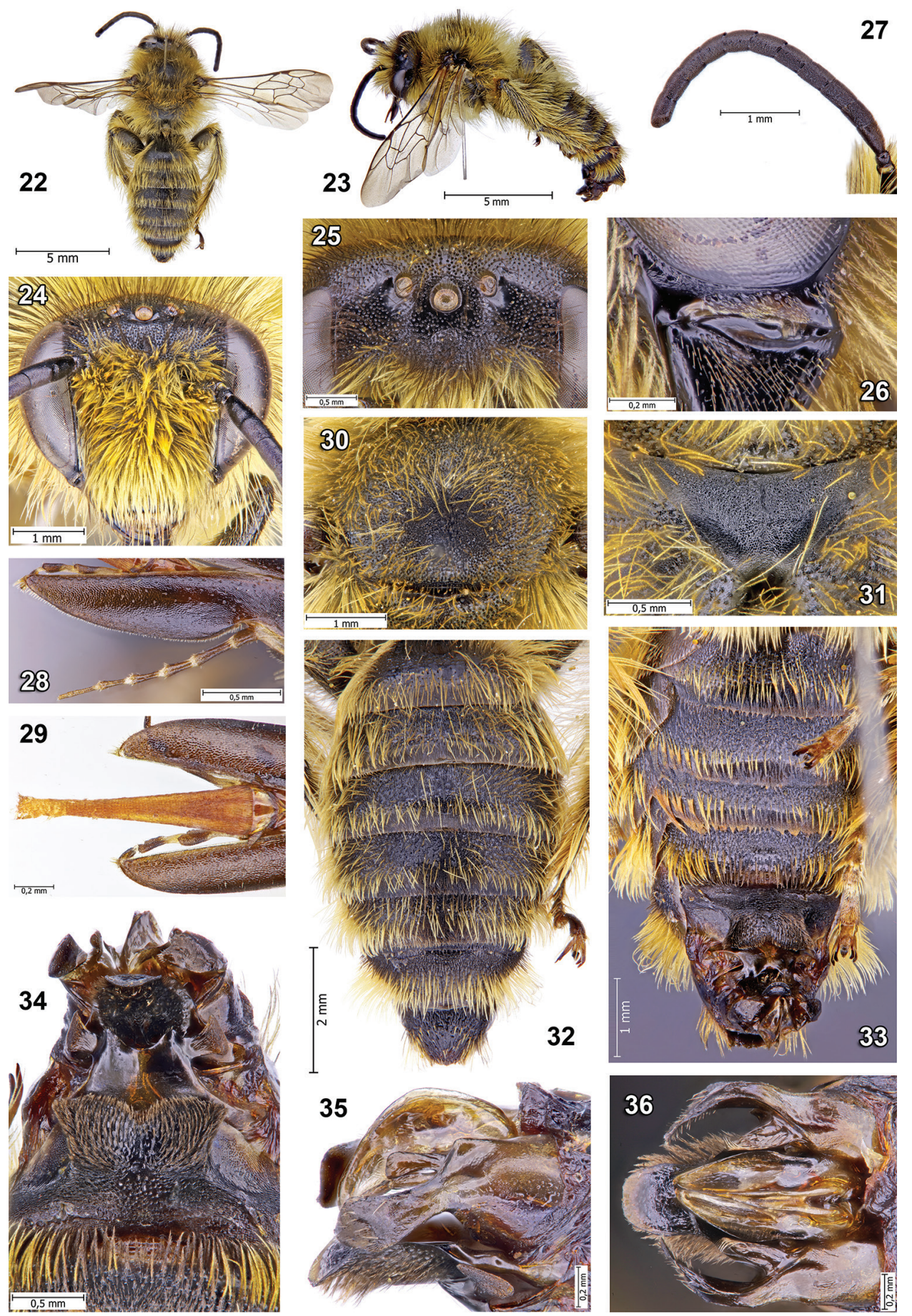

Figures 22-36. Male of D. michezi from Algarve, southern Portugal 22 dorsal view 23 lateral view $\mathbf{2 4}$ head (frontal view) $\mathbf{2 5}$ vertex and ocelli $\mathbf{2 6}$ malar area $\mathbf{2 7}$ antenna $\mathbf{2 8}$ galea and maxillary palpus $\mathbf{2 9}$ glossa and labial palpus (dorsal view) $\mathbf{3 0}$ scutum $\mathbf{3}$ I propodeum $\mathbf{3 2}$ metasoma (dorsal view) $\mathbf{3} \mathbf{3}$ metasoma (ventral view) 34 S6-8 and genitalia (ventral view) 35 genitalia (lateral view) 36 genitalia (dorsal view). 
reported from a very small number of locations. We therefore assess the IUCN Red List criteria of D. michezi as Endangered with the code B1a+B2a (see discussion).

\section{Discussion}

In this work, we provide the first description of the female of Dasypoda michezi, a poorly known melittid bee endemic to the south of Portugal, and present a key for both sexes to all known species of the genus Heterodasypoda. We finally assess the conservation status of Dasypoda michezi as Endangered at the European scale following the IUCN protocol. Other known species of the subgenus Heterodasypoda are not under such threat. In particular, D. albimana is categorized NT, and D. morotei and D. pyrotrichia LC (Nieto et al. 2014).

\section{Taxonomy}

The female of D. michezi presents some singular morphological features compared to the rest of the Heterodasypoda species, including a clear differentiation in its color pattern from the morphologically closely related $D$. albimana, the most visible being the color of the pilosity of the mid-leg (white in D. albimana and dark brown dorsally in D. michezi). The species confirms the original combination of morphological characteristics of the female sex proposed by Michez et al. (2004) for the subgenus, namely (i) a clypeus entirely punctured with or without a median carina, (ii) a scopa bicolored, (iii) the disc of T2 with a rather straight marginal line, (iv) pygidial plate glabrous, (v) maxillary palpae and galea of a subequal length, (vi) the margin of the galea with setae along its entire length, (vii) a malar space shorter than the length of the pedicel and (viii) a prefurcal nervulus.

\section{Ecology and conservation}

In a context of global declines in bee populations (Potts et al. 2010), the restricted distribution of Dasypoda michezi in the south of Portugal ultimately raises questions about its conservation. Having a restricted distribution implies that, if they occur, all or most individuals will experience adverse conditions simultaneously (Gaston 1998) and, because endemic species present by definition a few sites for conservation intervention, they are inherently more vulnerable to extinction in a context of global changes, particularly climate and habitat change. Moreover, the very recent description of the species (in 2017) naturally means that it was not attributed to a conservation status in the Red List of European bees (Nieto et al. 2014). In the latter work, the subfamily Dasypodainae was amongst the most at risk with $25 \%$ of its species being threatened. The IUCN status assessed here, Endangered with the code B1a + B2a, closely recalls those of the other threatened Dasypoda that were all assessed at least with the criterion B2a (accompanied with b[iii]), a threat related to a combination of an overall small AOO, severely fragmented habitats or a low number of locations, and a 
continuous decline estimated for the quality of the habitat. These criteria are shared with a large number of other threatened bees in Europe (Nieto et al. 2014), highlighting the need to preserve the most suitable natural habitats for the bee fauna of the continent (Michez et al. 2019; Ghisbain et al. 2020b). The criterion b(iii), associated with a continuous decline of habitat quality, is not appropriate for the status of $D$. michezi given that the whole known distribution of the species is included in a protected area, the Parque Natural do Sudoeste Alentejano e Costa Vicentina. Long-term preservation of such protected habitats is especially critical for bees like Dasypoda due to their relatively specialized foraging behaviour (Michez et al. 2008), a characteristic that could make them especially susceptible to changes in their environment as they do not switch to alternative host plants (Scheper et al. 2014). Dasypoda bees rely on flower-rich environments, and the subgenus Heterodasypoda is mostly associated with Cistaceae and Asteraceae (Michez et al. 2004b, 2008; Ruiz 2013; Özbek 2014) with other records on Lamiaceae and Rosaceae (Michez et al. 2003, 2004b; Ruiz 2013). Radchenko (2017) highlights the association of the males of D. michezi with Cistus (Cistaceae) pollen, which is consistent with the floral choices of other representatives of the subgenus. Further work is needed to characterize in more detail the floral choices of Dasypoda michezi in this National Park and to estimate the population trends of its host plants in its restricted range. With global warming and its associated higher intensity of extreme weather events, such a monitoring of habitat quality is crucial in areas like southern Portugal where heat waves and fires are already frequent.

In addition to the need to characterize the habitats in which D. michezi occurs, more observations of the species are also required to precisely delineate the timing of its flight period. Heterodasypoda bees are known to fly from late spring to late summer: May-July for D. albimana (Michez et al. 2003), mostly May-August for D. morotei and D. pyrotrichia (Ornosa and Ortiz-Sánchez 1998, 2004; Grace 2010). Our new records combined with those of Radchenko (2017) suggest that the flight period of Dasypoda michezi encompasses April and May (late spring). Overall, given the growing evidence that significant phenological shifts and mismatches in plant-pollinator interactions following global warming are occurring (Duchenne et al. 2020; Gérard et al. 2020), further understanding the species phenology and floral associations during their flight period is a key to their effective conservation.

\section{Iberian Peninsula as an understudied hotspot of bee diversity}

Although Europe constitutes one of the most extensively studied areas in the world for bees (Michez et al. 2019), the very recent discovery and characterization of Dasypoda michezi in Portugal is not surprising. New bee species are still continuously described from the Iberian Peninsula (Müller 2012; Wood and Cross 2017; Kuhlmann and Smit 2018; Smit 2018; Wood et al. 2020a), a geographic area that constitutes a global hotspot not only for bee species diversity (Orr et al. 2020) but also for many other organisms (Gómez and Lunt 2007). In total, over 1000 bee species are known from Spain (Ortiz-Sánchez 2011, 2020) and 722 from Portugal (Baldock et al. 2018; Wood et al. 2020a). This high diversity is partly due to the role that the Peninsula played as a glacial 
refugium during the Quaternary (Hewitt 2011), as well as the Mediterranean climate of the region, combined with the striking diversity of habitats (i.e. a combination of meadows, scrublands, mountains, woodlands and coastlines). In particular, the Iberian Peninsula constitutes a center of diversity for both of the Dasypoda subgenera Microdasypoda and Heterodasypoda. The first subgenus includes four known species, with one species endemic to Iberia: D. iberica (Michez et al. 2004b; Radchenko et al. 2019). The second includes four species with two endemics: the currently studied D. michezi and also D. morotei (Michez et al. 2004b; Radchenko 2017). Despite the extremely rich bee diversity of the Iberian Peninsula however, both Spain and Portugal present a very high percentage of species assessed as "data deficient" in the European Red List (Nieto et al. 2014; Wood et al. 2020b). The present case further suggests that additional efforts are encouraged to characterize and monitor the highly diverse bee fauna of these understudied areas. Future projects that focus on understanding the ecology of endemic bee species and delineating more precisely their distributions are encouraged to assess the potential threats that these species could face in the near future.

\section{Acknowledgements}

The authors are grateful to Thomas J. Wood for helpful comments on the manuscript. We warmly thank Yulia Astafurova, Ian Cross, Jack Neff and an anonymous reviewer for their constructive comments and advice on the manuscript. The authors thank Michael G. Branstetter for kindly helping confirm the COI sequences of Dasypoda morotei. The research leading to this publication received funds from the Fonds de la Recherche Scientifique-FNRS (Brussels, Belgium) and "The support of the priority research areas development of Ukraine", KPKVK 6541230. GG is funded by a F.R.S.FNRS grant "Aspirant". DC and DM are partly funded by the F.R.S.-FNRS and the Fonds Wetenschappelijk Onderzoek (FWO) under the EOS project CLIPS (n³094785).

\section{References}

Baldock D, Wood TJ, Cross I, Smit J (2018) The Bees of Portugal. Entomofauna, Supplement 221: 1-164.

Duchenne F, Thébault E, Michez D, Elias M, Drake M, Persson M, Rousseau-Piot JS, Pollet M, Vanormelingen P, Fontaine C (2020) Phenological shifts alter the seasonal structure of pollinator assemblages in Europe. Nature Ecology and Evolution 4: 115-121. https://doi. org/10.1038/s41559-019-1062-4

Gérard M, Vanderplanck M, Wood T, Michez D (2020) Global warming and plant-pollinator mismatches. Emerging Topics in Life Sciences 4(1): 77-86. https://doi.org/10.1042/ ETLS20190139

Ghisbain G, Radchenko VG, Michez D (2018) Dasypoda morawitzi Radchenko 2016 (Apoidea - Melittidae - Dasypodaini), une espèce nouvelle pour la faune de France. Osmia 7: 10 13. https://doi.org/10.47446/OSMIA7.2 
Ghisbain G, Lozier JD, Rahman SR, Ezray BD, Tian L, Ulmer JM, Heraghty SD, Strange JP, Rasmont P, Hines HM (2020a) Substantial genetic divergence and lack of recent gene flow support cryptic speciation in a colour polymorphic bumble bee (Bombus bifarius) species complex. Systematic Entomology 45: 635-652. https://doi.org/10.1111/syen.12419

Ghisbain G, Michez D, Marshall L, Rasmont P, Dellicour S (2020b) Wildlife conservation strategies should incorporate both taxon identity and geographical context - further evidence with bumblebees. Diversity and Distributions 26(12): 1741-1751. https://doi. org/10.1111/ddi.13155

Gómez A, Lunt D (2007) Refugia within refugia: patterns of phylogeographic concordance in the Iberian Peninsula. Phylogeography of southern European refugia. Netherlands, Springer, 155-188. https://doi.org/10.1007/1-4020-4904-8_5

Grace A (2010) Introductory biogeography to bees of the Eastern Mediterranean and Near East (1 $1^{\text {st }}$ Edn.). Bexhill Museum, Bexhill, 284 pp.

Hebert PD, Penton EH, Burns JM, Janzen DH, Hallwachs W (2004) Ten species in one: DNA barcoding reveals cryptic species in the neotropical skipper butterfly Astraptes fulgerator. Proceedings of the National Academy of Sciences of the United States of America 101: 14812-14817. https://doi.org/10.1073/pnas.0406166101

Hewitt GM (2011) Mediterranean Peninsulas: The Evolution of Hotspots. In: Zachos F, Habel J (Eds) Biodiversity Hotspots. Springer-Verlag Berlin Heidelberg, 123-147. https:/doi. org/10.1007/978-3-642-20992-5_7

Kuhlmann M, Smit J (2018) Description of a new bee species from Spain, Colletes jansmiti Kuhlmann nov.sp., with a key to the females of the C. albomaculatus-group (Hymenoptera: Colletidae). Linzer Biologische Beiträge 50: 1249-1254.

Mace GM (2004) The role of taxonomy in species conservation. Philosophical Transactions of the Royal Society of London. Series B: Biological Sciences 359: 711-719. https://doi. org/10.1098/rstb.2003.1454

Michener CD (2007) The bees of the world, second edition. The Johns Hopkins University Press, Baltimore, 953 pp. [20 pls.]

Michez D, Patiny S, Gaspar C (2003) Dasypoda albimana Pérez, 1905 (Hymenoptera, Apoidea, Melittidae), espèce nouvelle pour la France et le Maroc. Bulletin de la Société entomologique de France 108(1): 61-64.

Michez D, Terzo M, Rasmont P (2004a) Révision des espèces ouest-paléarctiques du genre Dasypoda Latreille 1802 (Hymenoptera, Apoidea, Melittidae). Linzer biologische Beiträge 36(2): 847-900.

Michez D, Terzo M, Rasmont P (2004b) Phylogénie, biogéographie et choix floraux des abeilles oligolectiques du genre Dasypoda Latreille 1802 (Hymenoptera: Apoidea: Melittidae). Annales de la Société Entomologique de France, New Series 40(3-4): 421-435. https://doi.or g/10.1080/00379271.2004.10697431

Michez D, Patiny S, Rasmont P, Timmermann K, Vereecken NJ (2008) Phylogeny and hostplant evolution in Melittidae s.l. (Hymenoptera: Apoidea). Apidologie 39(1): 146-162. https://doi.org/10.1051/apido:2007048

Michez D, Patiny S, Danforth BN (2009) Phylogeny of the bee family Melittidae (Hymenoptera: Anthophila) based on combined molecular and morphological data. Systematic Entomology 34: 574-597. https://doi.org/10.1111/j.1365-3113.2009.00479.x 
Michez D, Pauly A (2012) A new species of the palaearctic genus Dasypoda Latreille 1802 (Hymenoptera: Dasypodaidae) from the Great Rift Valley in Ethiopia. Zootaxa 3181(1): 63-68. https://doi.org/10.11646/zootaxa.3181.1.5

Michez D, Rasmont P, Terzo M, Vereecken NJ (2019) Bees of Europe. Hymenoptera of Europe (Vol. 1) édition N.A.P., Paris, 552 pp.

Müller A (2012) New European bee species of the tribe Osmiini (Hymenoptera: Apoidea: Megachilidae). Zootaxa 3355: 29-50. https://doi.org/10.11646/zootaxa.3355.1.2

Nieto A, Roberts SPM, Kemp J, Rasmont P, Kuhlmann M, García Criado M, Biesmeijer JC, Bogusch P, Dathe HH, De la Rúa P, De Meulemeester T, Dehon M, Dewulf A, OrtizSánchez FJ, Lhomme P, Pauly A, Potts SG, Praz C, Quaranta M, Radchenko VG, Scheuchl E, Smit J, Straka J, Terzo M, Tomozii B, Window J, Michez D (2014) European Red List of Bees. Publication Office of the European Union, Luxembourg, 98 pp.

Ornosa C, Ortiz-Sánchez FJ (1998) Contribución al conocimiento de los melitidos ibéricos (Hymenoptera, Apoidea, Melittidae). Boletín de la Asociación española de Entomología 22(3-4): 181-202.

Ornosa C, Ortiz-Sánchez FJ (2004) Hymenoptera, Apoidea I. Fauna Ibérica (Vol. 23). In: Ramos MA, Alba J, Bellés X, Gonsálbes J, Guerra A, Macpherson E, Martin F, Serrano J, Templado J (Eds) Museo Nacional de Ciencias Naturales. CSIC, Madrid, 556 pp.

Ortiz-Sánchez FJ (2011) Lista actualizada de las especies de abejas de España (Hymenoptera: Apoidea: Apiformes). Boletín de la Sociedad Entomológica Aragonesa 49: 265-281.

Ortiz-Sánchez FJ (2020) Checklist de Fauna Ibérica.Serie Anthophila (Insecta: Hymenoptera: Apoidea) en la península ibérica e islas Baleares (edición 2020). In: Ramos MA, Sánchez Ruiz M (Eds) Documentos Fauna Ibérica, 14. Museo Nacional de Ciencias Naturales, CSIC. Madrid, [2 (sn)] 83 pp.

Özbek H (2014) Distribution data on the family Melittidae (Hymenoptera) of Turkey with considerations about their importance as pollinators. Turkish Journal of Zoology 38: 444459. https://doi.org/10.3906/zoo-1309-5

Potts SG, Biesmeijer JC, Kremen C, Neumann P, Schweiger O, Kunin WE (2010) Global pollinator declines: trends, impacts and drivers. Trends in Ecology \& Evolution 25: 345-353. https://doi.org/10.1016/j.tree.2010.01.007

Radchenko VG (2016) A new widespread European bee species of the genus Dasypoda Latreille (Hymenoptera, Apoidea). Zootaxa 4184(3): 491-504. https://doi.org/10.11646/zootaxa.4184.3.4

Radchenko VG (2017) A new bee species of the genus Dasypoda Latreille (Hymenoptera, Apoidea) from Portugal with comparative remarks on the subgenus Heterodasypoda Michez. Zootaxa 4350(1): 164-176. https://doi.org/10.11646/zootaxa.4350.1.10

Radchenko VG, Ghisbain G, Michez D (2019) Redescription of three rare species of Dasypoda bees with first description of D. iberica and D. tibialis females (Hymenoptera, Apoidea, Melittidae). Zootaxa 4700: 326-344. https://doi.org/10.11646/zootaxa.4700.3.2

Radchenko VG, Tomozii B, Ghisbain G, Michez D (2020) New data on the morphology and distribution of the cryptic species Dasypoda morawitzi Radchenko 2016 (Hymenoptera: Melittidae) with corrections of Dasypoda s. str. diagnosis. Annales de la Société Entomologique de France (N.S.). https://doi.org/10.1080/00379271.2020.1841570

Rasmont P, Franzen M, Lecocq T, Harpke A, Roberts S, Biesmeijer K, Castro L, Cederberg B, Dvorak L, Fitzpatrick U, Gonseth Y, Haubruge E, Mahe G, Manino A, Michez D, Neu- 
mayer J, Odegaard F, Paukkunen J, Pawlikowski T, Potts S, Reemer M, Settele J, Straka J, Schweiger O (2015) Climatic Risk and Distribution Atlas of European Bumblebees. BioRisk 10: 1-236. https://doi.org/10.3897/biorisk.10.4749

Ruiz JL (2013) Fuentes alimenticias de los Melittidae ibéricos. Micobotánica-Jaén 8(3): 18-22. Scheper J, Reemer M, van Kats R, Ozinga WA, van der Linden GTJ, Schaminee JHJ, Siepel H, Kleijn D (2014) Museum specimens reveal loss of pollen host plants as key factor driving wild bee decline in The Netherlands. Proceedings of the National Academy of Sciences 111(49): 17552-17557. https://doi.org/10.1073/pnas.1412973111

Wandeler P, Hoeck PE, Keller LF (2007) Back to the future: museum specimens in population genetics. Trends in Ecology and Evolution 22(12): 634-642. https://doi.org/10.1016/j. tree.2007.08.017

Weissmann JA, Picanço A, Borges PAV, Schaefer H (2017) Bees of the Azores: an annotated checklist (Apidae, Hymenoptera). ZooKeys 642: 63-95. https://doi.org/10.3897/zookeys.642.10773

Wendzonka J, Celary W, Klejdysz T, Krzysztofiak A, Pawlikowski T, Posłowska J, Rutkowski T, Twerd L, Żurawlew P (2020) Dasypoda morawitzi Radchenko 2016 (Hymenoptera, Apoidea) a new species in the Polish fauna. Ampulex 11: 5-8.

Wood TJ, Cross I (2017) Camptopoeum (Camptopoeum) baldocki spec. nov., a new panurgine bee species from Portugal and a description of the male of Flavipanurgus fuzetus Patiny (Andrenidae: Panurginae). Zootaxa 4254(2): 285-293. https://doi.org/10.11646/ zootaxa.4254.2.9

Wood TJ, Cross I, Baldock D (2020a) Updates to the bee fauna of Portugal with the description of three new Iberian Andrena species (Hymenoptera: Apoidea: Anthophila). Zootaxa 4790(2): 201-228. https://doi.org/10.11646/zootaxa.4790.2.1

Wood T, Michez D, Paxton R, Drossart M, Neumann P, Gerard M, Vanderplanck M, Barraud A, Martinet B, Leclercq N, Vereecken NJ (2020b) Managed honey bees as a radar for wild bee decline? Apidologie 51: 1100-1116. https://doi.org/10.1007/s13592-020-00788-9 